\title{
Lingwistyczne aspekty komunikacji językowej osób starszych
}

\section{The linguistic aspects of the elderly people language communication}

Monika Stolarczyk-Zielonka

Instytut Dziennikarstwa i Komunikacji Spolecznej,

Uniwersytet Warmińsko-Mazurski

ul. Obitza, 10-725 Olsztyn

\begin{abstract}
Abstrakt
The main purpose of the herein article is to describe the language and curiosity of the elderly people communication. This article presents basic biological, social and psychological changes occurring together with ageing and their impact on the elderly people linguistic attributions. All enclosed conclusions are supported by professional literature as well as by remarks coming from the field research carried out among people over 60 years old.
\end{abstract}

\section{Wprowadzenie}

Artykuł zachęca do zwrócenia uwagi na niedostrzegane do tej pory zagadnienie językoznawcze, jakim jest język i komunikacja językowa osób starszych. Dotychczasowe wysiłki uczonych, zajmujących się rozwojem języka i kompetencji komunikacyjnych, dotyczyly przede wszystkim najmłodszej grupy wiekowej, czyli dzieci. Dzięki licznym i wieloaspektowym badaniom w tym zakresie powstała obszerna literatura dotycząca omawianego zagadnienia. 
W oparciu na niej możliwe jest uchwycenie pewnych zależności i etapów w rozwoju językowym dzieci, ale także zauważenie nieprawidlowości. Na tej podstawie istnieje szansa na ich szybkie dostrzeżenie i, w miarę możliwości, korygowanie.

Okres starości charakteryzuje się wieloma zmianami zachodzącymi w różnych sferach życia ludzkiego, co w konsekwencji prowadzi do zmian językowych i komunikacyjnych. Wyznaczenie określonych zależności może stać się pomocne w utrzymaniu dobrych kompetencji językowych przez ludzi starych. Należy także dodać, iż dorobek językoznawców dotyczący omawianego zagadnienia jest niezwykle skromny. Wszelkie informacje dotyczące starzenia się pochodzą ze źródel psychologicznych, biologicznych bądź socjologicznych. Dopiero w oparciu na nich powstają nieliczne wnioski językoznawcze.

\section{Biologiczne, psychiczne i spoleczne aspekty starzenia się i ich oddziaływanie na język oraz kompetencje komunikacyjne}

Komunikacja językowa należy do najważniejszych aspektów funkcjonowania ludzi w spoleczeństwie. Składa się na nią szereg umiejętności, w tym intelektualnych (mówienie, rozumienie, czytanie itd.), których opanowanie i wysoki poziom wykwalifikowania gwarantuje efektywność zdarzeń komunikacyjnych zachodzących między ludźmi. Z doniosłej roli języka i komunikacji językowej w życiu czlowieka zdawali sobie sprawę nie tylko językoznawcy, ale także badacze pozostający w kręgu innych specjalności, takich jak psychologia czy socjologia. Wiele uwagi skierowano więc w stronę badań nad rozwojem języka u dzieci w procesie ontogenezy. Wieloaspektowe eksperymenty w tym zakresie, przeprowadzone przez takich uczonych jak: Piaget, Wygotski, Luria (Luria 1976), poszerzyly wiedzę na temat nabywania języka i zdolności komunikacyjnych przez czlowieka i stworzyly bogate zaplecze naukowo-badawcze. Na jego podstawie wiadomo, że język i kom- 
petencje komunikacyjne są uwarunkowane przez szereg czynników społecznych, psychologicznych i biologicznych.

W ostatnich dziesięcioleciach w spoleczeństwie odnotowuje się wzrastajacy odsetek ludzi starszych. W obliczu tego procesu demograficznego zasadnym wydaje się być zwrócenie uwagi na język i komunikację językową tej grupy osób.

Starzenie się jest nieuchronnym etapem życia każdego czlowieka. „Czlowiek rośnie i rozwija się przez jedna czwarta cześć swojego życia, a przez trzy czwarte - starzeje się" (Bromley 1969: 13). Proces starzenia się jest zlożony i obejmuje każdą sferę ludzkiego funkcjonowania, należy więc domniemywać, że w konsekwencji także dotyka sferę językową.

Starzenie się dla wielu osób to przede wszystkim zmiany w fizjologii organizmu. W wieku starczym, podobnie zreszta jak i w dzieciństwie, dokonujace się zmiany biologiczne mają większe znaczenie i wplyw na funkcjonowanie czlowieka, z tajednak różnica, że w dzieciństwie przyczyniają się do rozwoju jednostki, a w okresie starości mają charakter destrukcyjny. Jak podaje Stuart-Hamilton (2000: 21), „w okresie późnej doroslości wszystkie ukryte zdolności do rozwoju zostaly zrealizowane, pozostały jedynie późno dzialające możliwości degradacji”".

Czynnikiem, z którym wiąże się niewatpliwie okres starości jest pogarszajacy się stan zmysłów, takich jak wzrok, słuch oraz obniżające się sprawności motoryczne organizmu. Informacje dostarczane do mózgu za pośrednictwem tych zmysłów nie sa już tak spójne, są mniej szczególowe i ich dostarczanie zajmuje więcej czasu, niż u osób młodych. „Wyraźny ubytek w procesie percepcji wynika z faktu, iż stary umysl jest mniej biegly w scalaniu informacji sensorycznej w jedną spójną calość" (Stuart-Hamilton 2000: 34).

Wraz z wiekiem spada także ciężar mózgu, a co się z tym wiąże, zmniejsza się ilość komórek nerwowych odpowiedzialnych za efektywność i szybkość uczenia się. Ludzie starsi wolniej więc przyswajają nową wiedzę, wolniej zapamiętuja, mają slabsze zdolności adaptacyjne. Wiek w znacznym stopniu oddzialywa również na pamięć, która jest niezbędnym czynnikiem funkcjonowania umysłowego. „Spadek liczby i sprawności neuronów odpowie- 
dzialnych za zapamiętywanie i przetwarzanie nowych informacji oznacza, że fizyczny system pamięci jest nieustannie nastawiony na szwank" (Stuart-Hamilton: 113). Dzięki sprawnie działającym systemom pamięciowym możliwe jest uczenie się rzeczy nowych, przypominanie i odtwarzanie informacji przyswojonych już wcześniej. Jako że pamięć u ludzi w wieku powyżej sześćdziesięciu lat przejawia tendencję do pogarszania się, to konsekwencją tego faktu może być stopniowe obniżanie sprawności intelektualnych, w tym zdolności językowych i komunikacyjnych. Badania nad procesami pamięci w okresie starości pokazują że pamięć bezpośrednia, czyli ta, która jest odpowiedzialna za przywoływanie treści znajdujących się w polu uwagi, zmniejsza swoje możliwości. Pamięć pośrednia natomiast wskazuje na to, że ludzie w wieku podeszlym maja problemy z odwolywaniem się do treści, rzeczy, wydarzeń, które przestaly być obiektem ich rozważań. Bez większych trudności korzystają $z$ wiedzy i doświadczenia, do których powracają myślami (por. Zych 1999).

W wieku starczym obserwuje się także inne trudności na poziomie językowym. Należy do nich zaliczyć zaburzenia mowy wywolywane przez różne czynniki, na przykład problemy ze słuchem, ale także zmiany zachodzace w mózgu. Narządy mowy są kontrolowane przez wiele jego sfer, uszkodzenie jakiejkolwiek z nich w wyniku choroby czy innego zdarzenia powoduje utrudnienia w procesie mówienia. Zaburzenia mowy moga być rezultatem afazji mózgu. „Zaburzenia afatyczne są uszkodzeniami okolic mózgu spelniających funkcje intelektualne" (Maruszewski: 1970: 45). Jeden z rosyjskich uczonych, Luria, zajmujący się obserwacja osób z afazją zauważył, że za schorzenie te odpowiada uszkodzenie sluchu fonematycznego, odpowiedzialnego za wszelkie czynności mowne. Kolejna przyczyną problemów komunikacyjnych osób starszych może być tak zwana słuchowa pamięć słowna, dzięki której możliwe jest zapamiętywanie słów i ich brzmienia, jak również jest niezbędna przy interpretowaniu mowy słyszanej. W przypadku wystapienia zaburzeń afatycznych również mowa wewnętrzna, warunkująca produkowanie wypowiedzi nie spelnia swoich funkcji. 
Jak wcześniej wspomnialam, skutkiem starzejącego się mózgu są różnego rodzaju choroby, w tym demencja starcza, inaczej zwana otępieniem. Demencja odnosi się wyłącznie do sfery psychicznej. Otępienie jest zespolem objawów zaburzeń procesów poznawczych obejmujących oprócz zaburzeń pamięci, deficyty różnych funkcji poznawczych, w tym mowy, zdolności rozpoznawania i identyfikacji ludzi i przedmiotów, ale także planowania i kontroli własnych zachowań. Obniżanie zdolności intelektualnych ma duże znaczenie dla komunikacji językowej osób starszych. Zaburzenia pamięci, zmiany w mózgu, liczne choroby w sposób destrukcyjny odbijają się na kompetencjach językowych, powodując problemy z mówieniem, formulowaniem myśli, mówieniem na określony temat, rozumieniem, a niejednokrotnie uniemożliwiają interakcje $z$ otoczeniem.

Niektóre ze zmian następujacych w wyniku starzenia się są nieuchronne. Na niektóre $z$ nich można w określony sposób oddzialywać i, tym samym, spowalniać ich degradujace dzialanie. Nie mniej jednak potrzeba świadomości tych zmian oraz wiedzy na ich temat. W nielicznych pracach gerontologicznych rzadko i niewiele uwagi poświęca się wplywowi starzenia się na zdolności językowe, poza pobieżnymi stwierdzeniami dotyczącymi zmian w fizjologii mózgu.

Starzenie się przejawia się nie tylko w biologicznej sferze, ale także powoduje zmiany spoleczne i psychiczne. Jedną z najbardziej widocznych oznak społecznego starzenia się jest wy cofywanie się z aktywności zawodowej. Wedlug niektórych ocen (GUS) ${ }^{1}$, Polak przeciętnie przechodzi na emeryturę $\mathrm{w}$ wieku pięćdziesięciu siedmiu lat, mając przed soba perspektywę co najmniej dwudziestu lat życia. $Z$ momentem przejścia na emeryturę wiąże się wiele konsekwencji. Następuje ograniczenie kontaktów z innymi ludźmi, ograniczenie obowiązków, zmienia się styl życia. Niektórzy ludzie z uporem bronią się przed przejściem na emeryturę, obawiając się odseparowania i ograniczenia kontaktów ze spoleczeństwem. Mimo to ,wycofywanie z życia musi nastapić, gdyż czlowiek stary

http://www.mpips.gov.pl/bip/download/Uzasadnienie_03_06.pdf [dostęp: 05.2009] 
odczuwa brak sil fizycznych i intelektualnych" (Bromley 1969: 84). Rezultatem tego są najczęściej rzadsze kontakty z innymi ludźmi, co zmniejsza liczbę interakcji językowych. Słabnące zwiazki $z$ otoczeniem sprzyjają wykształceniu się postawy egocentrycznej przejawiającej się w zainteresowaniu tylko swoimi problemami, swoim życiem, traktowaniu swojego zdania jako jedynie słusznego. U osób starych pojawia się tak zwana mowa egocentryczna, dzięki której ludzie ci absorbują uwagę otoczenia, ale także sprowadzają je do wlasnej osoby.

Poprzez ograniczenie aktywności zawodowej umysł ludzki nie jest już zmuszany do intensywnego wysilku intelektualnego. Odzwierciedla się to także w języku. Człowiek stary jest mniej efektywny w wyrażaniu się, obniża się poprawność wytwarzanych komunikatów, a także zmniejszają się zdolności do wzbogacania języka o nowe slowa i wyrażenia. Wiele slów zostaje zapomnianych i wychodzi z wlasnego slownika umyslowego. Slownik umyslowy to pewien zasób slów, których czlowiek używa podczas codziennych operacji językowych. Aby dane slowo zostalo odnalezione w słowniku umyslowym, czlowiek potrzebuje bodźca z zewnątrz. Takim bodźcem jest widziany przedmiot czy też inne słowo. Zostają wtedy uruchomione informacje ortograficzne, fonologiczne i semantyczne, które są następnie sumowane. Wraz z wiekiem dostęp do owego slownika ulega pogorszeniu. Wiąże się to z obniżającymi się zdolnościami mózgu w przewodzeniu bodźców z zewnątrz, ale także ze zmniejszeniem się liczby dostarczanych bodźców.

W okresie starości następuje także wycofywanie się z życia kulturalnego, co prowadzi do zamykania się w kręgu wlasnych doświadczeń, rodzi się poczucie zacofania i frustracji. Czlowiek stary czuje się zapomniany, odizolowany, samotny. Pod wplywem takiej sytuacji w ich zachowaniach komunikacyjnych wyksztalca się coś na wzór mowy egocentrycznej, która jako naturalne stadium rozwoju językowego pojawia się u dzieci. Celem owego zachowania jest chęć zwrócenia na siebie uwagi, organizacja wlasnego działania, ale także wypelnienie pustki w kontaktach interpersonalnych.

Wszystkie przytoczone powyżej przyklady oddziaływania wieku na zdolności językowe dotykają tylko niektórych zagadnień związa- 
nych z tematem i stanowią punkt wyjścia do bardziej szczególowych i prowadzonych na większą skalę badań w tym zakresie.

Czasu starości nie należy traktować jako calkowitej degradacji jednostki. Jak wykazuja badania (Bromley 1969: 128), ludzie którzy w okresie mlodości i dorosłości dbali o swój rozwój i wykształcenie w okresie ,późnej dorosłości" mają więcej cech świadczących o ich lepszym przystosowaniu do stawania się czlowiekiem starym. Częściej niż inne osoby w tym wieku są zdolni dostrzec korzyści plynące z faktu bycia starym, umieją zachować zdolność do samodzielnego myślenia oraz dbają o swój rozwój intelektualny i duchowy.

Tajemniczy proces starzenia sie nie jest jednoznaczny ze schodzeniem w ciemną dolinę; o wiele bardziej przypomina wspinanie się na ostatni szczyt, przed którym trzeba odłożyć zbędny bagaż. Oczywiście wspinaczka na szczyt jest męcząca. Jednak szczyt wiele również obiecuje: szeroki widok, który uzy skuje się tylko tam; inną perspektywę, spojrzenie na przebyta droge, dystans do tego, co się za soba pozostawiło; oddech, nowe widzenie, wolność od tego, co przygniata, być może nowe nastawienie do codzienności ${ }^{2}$.

\section{Analiza materiału badawczego}

W tej części artykulu przedstawione zostaną wyniki ankiety przeprowadzonej wśród 100 osób powyżej 60. roku życia.

Celem badania polowego bylo spostrzeżenie zmian następujących w języku i kompetencjach komunikacyjnych osób starszych. Jako że język jest tworem spolecznym, koniecznym wydalo się badanie go w naturalnym środowisku jego użytkowników. Taki sposób zbierania materiału sprawił, że wnioski są bardziej wymierne i odzwierciedlają rzeczywisty stan języka oraz kompetencji komunikacyjnych seniorów.

http://www.bochenia.pl/na-lini-czasu/2009/maj/zlota/jesien-czy-staroc.html [dostęp: 05.2009]. 
W celu zgromadzenia materialu badawczego przeprowadzone zostaly badania polowe w różnych instytucjach skupiajacych osoby starsze. Byly to domy opieki spolecznej, domy spokojnej starości, kluby seniora oraz uniwersytet trzeciego wieku.

Ankieta (narzędzie badawcze) skladala się z dwóch kategorii tematycznych, poruszających różne kwestie językowe. Pierwsza część dotyczyla zmian w języku i komunikacji językowej następujących wraz ze starzeniem się, druga zawierała pytania o leksykę.

\subsection{Interpretacja wyników ankiety}

Pierwszym z zaobserwowanych wniosków bylo spostrzeżenie różnic w sposobie komunikowania się osób mlodych i starych. Respondenci, świadomi istnienia takich rozbieżności zauważyli że:

- zmienia się tempo mówienia (starszym osobom wypowiedź zajmuje więcej czasu niż mlodym.);

- inna jest częstość mówienia (starsi w porównaniu z dziećmi i mlodzieżą mówią mniej.);

- różny jest zasób wykorzystywanego slownictwa;

- różna jest kultura wypowiadania się (Kultura językowa osób starszych jest wyższa niż mlodzieży.);

- zmniejsza się sprawność i efektywność w przekazywaniu informacji;

- mlodzież wykorzystuje nowoczesne technologie ułatwiajace kontakty interpersonalne, osoby starsze korzystaja z nich sporadycznie.

Obok powyższych różnic istotnym wydaje się przedstawienie w tym miejscu trudności językowych, z jakimi spotykają się w codziennych interakcjach ludzie starzy. Do najistotniejszych należy zaliczyć:

- brak odpowiedniego zasobu leksykalnego, pozwalającego na swobodę w wyrażaniu swoich myśli i uczuć, ale co ważniejsze, niezbędnego do nazywania nowych zjawisk i przedmiotów; 
- brak zrozumienia komunikatów przez osoby mlode, szczególne w przypadku używania słów i wyrażeń przestarzałych;

- brak znajomości żargonu mlodzieżowego;

- brak znajomości i nierozumienie slów obcego pochodzenia;

- w związku z pogarszającym się stanem pamięci zapominanie słów i kwestii, które chciało się powiedzieć;

- trudności komunikacyjne wynikające z pogarszającego się stanu zmysłów, słuchu, wzroku oraz gorszej sprawności motorycznej (zwlaszcza wykorzystywanej przy pisaniu), co zmniejsza poczucie komfortu w relacjach z innymi ludźmi, a to z kolei skutkuje ich ograniczaniem.

- brak wiedzy na temat nowych możliwości komunikacji z otoczeniem, np. za pomoca internetu.

Wykorzystujacc doświadczenie i wiedzę ankietowanych nagromadzoną na przestrzeniu wielu lat życia, można prześledzić także różnice, jakie nastapily w języku polskim. Najbardziej odczuwalnymi, zdaniem badanych, sa:

- obniżenie kultury kontaktów interpersonalnych, ze szczególnym akcentem polożonym na relacje kobieta-mężczyzna, osoba starsza-osoba mloda;

- pojawienie się nadmiaru słów obcego pochodzenia i moda na zastępowanie nimi slów rdzennie polskich;

- brak dbalości o kulturę i poprawność językowa, zwłaszcza w internecie;

- przekształcanie, upraszczanie i skracanie wyrazów języka polskiego, szczególnie zwrotów grzecznościowych, powitalnych, pożegnalnych;

- nadawanie osobom, przedmiotom, zjawiskom innych określeń, nazw;

- technicyzacja, ekonomizacja i informatyzacja języka polskiego wzrastająca wraz z rozwojem tych dziedzin.

Jako uzupelnienie poprzedniego wniosku należy dodać brak znajomości języków obcych przez osoby starsze. Problem ten przedstawia się następujaco:

- $60 \%$ ankietowanych uczylo się w dzieciństwie i wczesnej mlodości języka rosyjskiego, przy czym tylko 7\% badanych deklaruje 
zaawansowany poziom znajomości języka, 15\% średniozaawansowany, a 38\% - komunikatywny;

- $24 \%$ osób starszych nie deklaruje znajomości jakiegokolwiek języka obcego;

- $13 \%$ zaznacza, że zna język angielski, przy czym 5\% operuje językiem w stopniu zaawansowanym, a 8\% w stopniu komunikatywnym;

- $3 \%$ uczyło się języka niemieckiego, przy czym okolo $1 \%$ z grupy badanych zna go w stopniu zaawansowanym, reszta - w stopniu komunikatywnym ${ }^{3}$.

Kolejne pytanie dotyczylo form komunikacji interpersonalnej i zmian zachodzacych na tym poziomie. Formy komunikacyjne to w tym rozumieniu mówienie, shuchanie i rozumienie oraz pisanie, a także wykorzystywanie różnych kanałów do przekazywania i wymiany informacji.

Dane $\mathrm{z}$ ankiety pozwolily na uzyskanie następujących wniosków:

- wraz z wiekiem najczęściej następuje ograniczenie liczby kontaktów interpersonalnych, co może być skutkiem wycofywania się z aktywności zawodowej i spolecznej ${ }^{4}$;

- u większości respondentów zachowania językowe ograniczają się jedynie do mówienia i słuchania, rzadziej wykorzystują pisemne formy kontaktu;

- w porównaniu do młodzieży i osób aktywnych zawodowo, osoby starsze korzystają z mniejszego spektrum możliwości kontaktów interpersonalnych. Rzadko wykorzystują nowe, na przyklad, internetowe formy komunikacji międzyludzkiej.

Kolejna $z$ analizowanych kategorii - leksyka i frazeologia - wzbogacila rozważania na temat języka osób starszych o nowe

3 Dane te zostaly uzyskane na podstawie subiektywnych odczuć osób ankietowanych i nie byly sprawdzane na podstawie testów kompetencji.

4 Konsekwencją niedostatku kontaktów z otoczeniem jest „mówienie do siebie”. Ten typ zachowania przy pomina mowę zewnętrzną u dzieci, które za jej pomocą organizują sobie swoją przestrzeń i dzialanie. Można więc domniemywać, iż podobnie ludzie starzy działając w jakimś określonym kierunku jednocześnie mówią chcąc ulatwić działanie. 
wnioski. Jedno z pytań w niej zawartych dotyczyło znajomości słów obcego pochodzenia. W grupie podanych słów znalazły się: abdykacja, abolicja, elektorat, e-mail, hipochondria, inflacja, kosmopolityzm, lifting, make-up, marketing, on-line, public relations, racjonalizm. Byly to slowa wybrane losowo ze slownika wyrazów obcych. Zadaniem ankietowanych bylo wythumaczenie ich znaczenia i zapisanie go. $\mathrm{Na}$ tej podstawie oceniana byla trafność rozumienia podanych leksemów. W tabeli zamieszczonej na kolejnej stronie artykuhu, w prawej kolumnie zostal podany procent prawidlowych interpretacji na sto osób. Dla porównania podobny eksperyment zostal przeprowadzony w grupie osób młodych. Dzięki temu możliwe stalo się skonfrontowanie omawianej kompetencji w dwóch ant agonicznych grupach. Poziom rozumienia słów obcego pochodzenia rozkladal się następująco:

Wyniki ankiety nt. znajomości znaczenia slów obcego pochodzenia w grupie seniorów

\begin{tabular}{ll} 
slowo & trafne interpretacje \\
\hline abdykacja & $69 \%$ \\
\hline abolicja & $6 \%$ \\
\hline elektorat & $38 \%$ \\
\hline e-mail & $14 \%$ \\
\hline hipochondria & $23 \%$ \\
\hline inflacja & $22 \%$ \\
\hline kosmopolityzm & $12 \%$ \\
\hline lifting & $35 \%$ \\
\hline make-up & $36 \%$ \\
\hline marketing & $22 \%$ \\
\hline on-line & $6 \%$ \\
\hline public relations & $18 \%$ \\
\hline racjonalizm & $35 \%$
\end{tabular}


Uklad procentowy przykładów zamieszczonych w powyższej tabeli informuje, że stopień znajomości slów obcego pochodzenia u seniorów jest niski. Wniosek ten potwierdza wcześniejsze spostrzeżenia dotyczące trudności komunikacyjnych oraz znajomości języków obcych.

Wyniki ankiety nt. znajomości znaczenia słów obcego pochodzenia w grupie mlodzieży

\begin{tabular}{ll} 
slowo & trafne interpretacje \\
\hline abdykacja & $81 \%$ \\
\hline abolicja & $11 \%$ \\
\hline elektorat & $65 \%$ \\
\hline e-mail & $98 \%$ \\
\hline hipochondria & $62 \%$ \\
\hline inflacja & $8 \%$ \\
\hline kosmopolityzm & $34 \%$ \\
\hline lifting & $57 \%$ \\
\hline make-up & $99 \%$ \\
\hline marketing & $57 \%$ \\
\hline on-line & $89 \%$ \\
\hline public relations & $57 \%$ \\
\hline racjonalizm & $75 \%$
\end{tabular}

Jak ukazuje tabela, osoby mlode w większym stopniu trafnie interpretuja znaczenie slów obcego pochodzenia. Jest to zależne od lepszej znajomości języków obcych, dostępu do różnych źródeł informacyjnych oraz aktywnego uczestnictwa w procesie ksztalcenia. Osoby starsze dużo częściej dokonują interpretacji tych słów na podstawie różnego rodzaju podobieństw i analogii.

Brak znajomości slów obcego pochodzenia utrudnia rozumienie języka ojczystego. Ludzie starsi nie podejmuja jednakże dzialań 
majacych na celu pokonanie tych barier komunikacyjnych, nie wykorzystuja wiedzy innych i nie korzystaja ze różnego rodzaju slowników. W rezultacie zdarza się, że seniorzy używają tych slów w nieprawidlowym kontekście lub w zmienionym znaczeniu.

Kolejnym omawianym aspektem była poprawność form leksykalnych. Wyniki badania zostaną przedstawione na stronie kolejnej.

Wyniki ankiety nt. poprawności form leksykalnych

$\begin{array}{lll}\text { Forma leksykalna } & \begin{array}{c}\text { prawidlowe } \\ \text { odpowiedzi }\end{array} & \begin{array}{l}\text { nieprawidlowe } \\ \text { odpowiedzi }\end{array}\end{array}$

\begin{tabular}{lll}
\hline doktor $^{8}$ - doktór & $30 \%$ & $70 \%$ \\
\hline dyrektor - derektor & $65 \%$ & $35 \%$ \\
\hline pszczoła - przczola & $37 \%$ & $63 \%$ \\
\hline $\begin{array}{l}\text { mężczyzna - męszczy- } \\
\text { zna - menszczyzna }\end{array}$ & $46 \%$ & $54 \%$ \\
\hline ksztalt - krztalt & $65 \%$ & $35 \%$ \\
\hline $\begin{array}{l}\text { żolnierz - żolnież } \\
\text { - rzolniesz }\end{array}$ & $74 \%$ & $26 \%$ \\
\hline wziąć - wziąść & $26 \%$ & $74 \%$ \\
\hline ważyć - warzyć & $82 \%$ & $18 \%$ \\
\hline przeklinać - pszeklinać & $83 \%$ & $17 \%$
\end{tabular}

Zasadniczym celem powyższego badania było sprawdzenie znajomości regul ortograficznych oraz poprawności podanych wyrazów. Charakterystycznym jest fakt, iż ortografia nie sprawia tak dużych problemów, jak wybór prawidlowej formy leksemu.

$\overline{8}$ Pierwsza forma wyrazowa w tabeli jest formą zgodną z norma językowa. 
Wyniki ankiety nt. poprawności gramatycznej zwrotów frazeologicznych

\begin{tabular}{lll} 
Zwrot frazeologiczny & $\begin{array}{l}\text { Forma pra- } \\
\text { widlowa }\end{array}$ & $\begin{array}{l}\text { Forma nie- } \\
\text { prawidlowa }\end{array}$ \\
\hline $\begin{array}{l}\text { Dreszcz przeszedl kogoś po } \\
\text { plecach }\end{array}$ & $100 \%$ & $0 \%$ \\
\hline $\begin{array}{l}\text { Dreszcz przeszedl komuś } \\
\text { po plecach }\end{array}$ & $100 \%$ & $0 \%$ \\
\hline Rzucać się w oczy & $100 \%$ & $0 \%$ \\
\hline Rzucać się w uszy & $47 \%$ & $53 \%$ \\
\hline Shucham Paniq? & $100 \%$ & $0 \%$ \\
\hline Shucham Pani? & $100 \%$ & $0 \%$
\end{tabular}

Używając związków frazeologicznych, użytkownicy języka najczęściej nie zastanawiają się nad ich poprawnością gramatyczna, ponieważ figurują one w języku jako utrwalone formy, w związku z czym wydają się być zawsze prawidlowymi. Tymczasem w większości przypadków ludzie wykorzystują blędną wersję.

W przypadku pierwszym forma prawidlowa jest Dreszcz przeszedl komuś po plecach. Druga forma jest prawidłowa tylko wtedy, gdy powiemy Dreszcz przeszedl kogoś. Blędną formę zwrotu frazeologicznego, czyli Dreszcz przeszedl kogos po plecach, użyło $100 \%$ ankietowanych.

Podobnie w przypadku trzecim, prawidlową formą używana, np. podczas rozmowy telefonicznej jest zwrot Stucham Paniq? Slucham Pani? wyraża jedynie posluszeństwo osoby sluchającej i tylko w takim przypadku jest zdaniem prawidlowym. Jest to konstrukcja czasownika z dopełniaczem. Dla okazania gotowości sluchania, tak jak to się dzieje w przypadku rozmowy telefonicznej, używa się konstrukcji z biernikiem: Shucham Panią? W czym mogę pomóc?

W przypadku drugim prawidlową i utrwalona forma jest zwrot Rzucać sie w oczy, czyli inaczej mówiąc - dać się zauważyć. 
O uszach mówi się raczej, że coś się obiło o uszy lub wpadło w ucho. Trafność ocen w przypadku Rzucać sie w oczy wyniosla 100\%, w przypadku Rzucać sie w uszy $47 \%$.

\section{Podsumowanie}

Na podstawie ankiet uzupelnionych przez osoby starsze możliwe stalo się stwierdzenie, że podobnie jak język dzieci w procesie ontogenezy, tak również język doroslych podlega ewolucji wywolanej rozmaitymi czynnikami spolecznymi, biologicznymi czy psychicznymi. Inny jest tylko kierunek i intensywność tych zmian. U osób starszych przyczyniają się one do pogarszania kompetencji językowych i komunikacyjnych, u dzieci - do rozwoju.

Język jest zwierciadłem rzeczywistości. Tak jak zmienia się otaczający świat, tak język dostosowuje się do nowych potrzeb. Wymaga to od użytkowników języka aktywności w dostosowywaniu się do tychże zmian.

W ostatnich latach wiele mówi się na temat jakości życia seniorów. Pojęcie jakości traktowane jest bardzo szeroko i zawiera w sobie troskę o zdrowie, poczucie bezpieczeństwa, ale także zapewnienie godnego traktowania przez innych. Stosunkowo niedawno do listy tej dolączyly możliwości bycia kreatywnym oraz dbalość o wrażenia estetyczne.

Tak szerokie traktowanie zagadnienia godziwej starości nie uwzględnia jednak zagadnień związanych z językiem i komunikacją językowa, która jest przecież nieodlącznym elementem spolecznego funkcjonowania.

\section{Bibliografia}

Bromley, D. B. 1969. Psychologia starzenia się. Warszawa: Wydawnictwo PWN.

Gryzlo, H. 2009, Ztota jesień czy starość. http://www.bochenia.pl/na-liniczasu/2009/maj/zlota/jesien-czy-staroc.html [dostęp dnia: maj 2009] 
Dryll, I. 2006. Zbyt wczesny fajrant: dezaktywacja zawodowa Polaków. http://www.mpips.gov.pl/bip/download/Uzasadnienie_03_06.pdf [dostęp dnia: maj 2009]

Luria, A. R. 1976. Podstawy neuropsychologii. Warszawa: Wydawnictwo PWN.

Maruszewski, M. 1970. Mowa a mózg. Zagadnienia neuropsychologiczne. Warszawa: Wydawnictwo PWN.

Stuart-Hamilton, I. 2000. Psychologia starzenia się. Poznań: Wydawnictwo Zysk i S-ka.

Zych,A.A. 1999. Czlowiek wobec starości: szkice z gerontologii spolecznej. Katowice: Wydawnictwo Śląsk. 